\title{
Polymorphisms of PHF11 and DPP10 Are Associated with Asthma and Related Traits in a Chinese Population
}

\author{
Jinming Gao ${ }^{a}$ Weijuan Li $^{a}$ Saffron A. Willis-Owen ${ }^{b}$ Lei Jiang ${ }^{a} \quad Y_{i}$ Ma ${ }^{a}$ Xinlun Tian ${ }^{a}$ \\ Miriam Moffatt ${ }^{\mathrm{b}}$ William Cookson ${ }^{\mathrm{b}}$ Yaoguang Lin ${ }^{\mathrm{a}}$ Youming Zhang ${ }^{\mathrm{b}}$

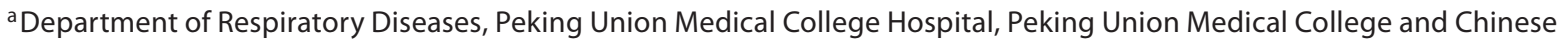 \\ Academy of Medical Sciences, Beijing, China; ${ }^{b}$ Molecular Genetics Group, Airway Disease Section, National Heart and \\ Lung Institute, Imperial College, London, UK
}

For editorial comment see p. 14

\section{Key Words}

Asthma DPP10 • Genetics $\cdot$ PHF11 - Single-nucleotide polymorphism

\begin{abstract}
Background: Initial studies by positional cloning have identified the genes encoding the plant homeodomain zinc finger protein 11 (PHF11) and dipeptidyl-peptidase 10 (DPP10) as asthma susceptibility genes. The variants in the two genes have been associated with asthma in several populations of European or Latin American origin. Objective: The aim of this study was to assess the common PHF11 and DPP10 polymorphisms for associations to asthma and asthma-related traits in a Han Chinese population. Methods: We genotyped six polymorphic markers in PHF11 and five polymorphic markers in DPP10 in a Han Chinese case-control cohort consisting of 408 asthma patients and 288 unrelated diseasefree controls recruited from the Northern region of China. We analyzed the association between these markers and asthma as well as a number of intermediate, asthma-related traits. Linkage disequilibrium and haplotype patterns were also evaluated. Results: Significant associations were identified between two makers in PHF11 (rs1046295 and rs16659) and asthma susceptibility (odds ratio, OR $=1.32,95 \%$ con-
\end{abstract}

fidence interval, $\mathrm{Cl}=1.06-1.65, \mathrm{p}=0.0096$, for $\mathrm{rs1046295}$, and $\mathrm{OR}=1.41,95 \% \mathrm{Cl}=1.12-1.75, \mathrm{p}=0.0026$, for $r \mathrm{~s} 16659)$. $\mathrm{A}$ strong association was observed between an SNP in DPP10 ( $r$ 10208402) and $\log _{\mathrm{e}}$-transformed total $\operatorname{lgE}(p=0.0003)$ and the percentage of peripheral blood eosinophils $(p=0.0023)$. A weak association between rs1430090 in DPP10 and forced expiratory volume in $1 \mathrm{~s}$ was also observed $(p=0.048)$. Haplotype analysis revealed two protective haplotypes in PHF11 against asthma. Conclusion: The results provide supporting evidence for genetic variants in PHF11 and DPP10 genes underlying asthma susceptibility and asthma-related quantitative traits in a Han Chinese population.

Copyright $\odot 2009$ S. Karger AG, Basel

\section{Introduction}

Asthma is one of the few chronic diseases occurring in both developed and developing countries. It is increasing in prevalence and one of the most common disorders

J.G., Y.L. and Y.Z. contributed equally to this work. This study has been accepted as a poster presentation at the ATS International Conference 2009 (San Diego).

\section{KARGER}

Fax +41613061234 E-Mail karger@karger.ch www.karger.com (c) 2009 S. Karger AG, Basel 0025-7931/10/0791-0017\$26.00/0

Accessible online at: www.karger.com/res
Jinming Gao, MD

1 Shuaifuyuan, Dongcheng District

Beijing 100730 (China)

Tel. +86 106529 5035, Fax +86106512 4875, E-Mail gaojm@pumch.cn 
encountered in clinical medicine in both children and adults. The genetic variants and environmental risk factors contribute almost equally to its course [1]. Since the first whole genome-wide linkage screening for asthma and allergy was completed in 1996 [2], several loci influencing asthma susceptibility or asthma-related traits have been identified by positional cloning and whole genome association [3-8]. The polymorphisms of the PHD finger protein 11 (PHF11) gene and the dipeptidyl-peptidase 10 (DPP10) gene were found to have associations with asthma and related traits by positional cloning $[4,5]$. The functions of the two genes are not fully understood. PHF11 on chromosome 13q14 is suggested to genetically impact asthma via serum total IgE regulation and altered Th1/Th2 cytokine release [4, 9]; DPP10, which is located on chromosome $2 \mathrm{q} 14$, is strongly associated with asthma susceptibility, possibly through regulating the activities of chemokines and cytokines [5].

Genetic risk factors for asthma have often differed among different populations [10]. This may be caused by phenotypic heterogeneity, different ethnicity and linkage disequilibrium (LD) patterns. Replication of the results in other populations provides strong evidence for associations, particularly for complex disease genes. In order to determine if polymorphisms in PHF11 and DPP10 also affect other populations, we tested six markers from chromosome 13 that covered PHF11 and five markers from chromosome 2 that covered DPP10 in a in a casecontrol study in a Han Chinese population.

\section{Patients and Methods}

\section{Subjects and Phenotype Definition}

We recruited 408 asthma patients and 288 controls with Han ethnicity from the Northern region of China. All subjects were unrelated. Asthma cases were recruited at the Pulmonary Clinic, Peking Union Medical College Hospital. Ethnicity-matched controls were selected from non-asthmatic, non-atopic, healthy individuals. The study protocol was approved by the Human Research Ethics Committee of the Peking Union Medical College Hospital, and all subjects gave written informed consent to participate in the study.

Measurement of serum total IgE was performed by applying the UniCAP System (Pharmacia, Uppsala, Sweden) according to the manufacturer's instructions.

Atopy was defined as $\geq 100 \mathrm{IU} / \mathrm{ml}$ of serum total $\operatorname{IgE}[11,12]$. All cases had current asthma symptoms including wheezing, cough, awakening at night and shortness of breath. Asthmatics with forced expiratory volume in $1 \mathrm{~s}\left(\mathrm{FEV}_{1}\right) \geq 70 \%$ of predicted underwent the methacholine challenge test, and positive bronchial hyperresponsiveness was defined by a $20 \%$ fall in $\mathrm{FEV}_{1}$ at inhaled methacholine concentrations $\leq 12.8 \mu \mathrm{mol}$. Patients with $\mathrm{FEV}_{1}<70 \%$ of predicted underwent an airway reversibility test, with positive airway reversibility defined by both $12 \%$ improvement in $\mathrm{FEV}_{1}$ and an increase $\geq 200 \mathrm{ml}$ in the absolute $\mathrm{FEV}_{1}$ value after $\beta_{2}$-agonist inhalation. Asthma diagnoses were made using the criteria defined by the American Thoracic Society [13].

\section{Genotyping}

DNA was collected from peripheral blood leukocytes by standard phenol-chloroform extraction. A total of eleven markers were genotyped. Single nucleotide polymorphisms (SNPs) were genotyped by means of restriction fragment length polymorphism polymerase chain reaction (PCR). Marker rs16659 is a 15-bp insertion/deletion polymorphism and was genotyped by direct loading of PCR products onto $4 \%$ agarose gel (see table 1 for detailed PCR information). In general, PCR cycle conditions were as follows. In total, 35 cycles were performed, each cycle consisted of (i) $60 \mathrm{~s}$ at $94^{\circ} \mathrm{C}$, followed by (ii) $60 \mathrm{~s}$ at $50-60^{\circ} \mathrm{C}$ and then (iii) $30 \mathrm{~s}$ at $72^{\circ} \mathrm{C}$. After PCR, products were subject to a 4 -hour enzymatic digestion including 2-4 units of enzyme per reaction. The reactions were then loaded onto $3-4 \%$ agarose gel for genotype scoring.

\section{Statistical Analysis}

All genotype and phenotype data were analyzed using PLINK. Genotype and allele frequencies in cases and controls were compared by contingency table analysis. Genotype relative risks were calculated according to the statistical method described by Lathrop [14]. This method compares case genotype frequencies with expected control genotype frequencies under the assumption of the Hardy-Weinberg equilibrium, and is more powerful than standard contingency table analysis.

Quantitative traits were tested using a variance component approach implemented in the statistical package Merlin [15]. Quantile normalization was applied to all quantitative traits prior to analysis (with the exception of total serum IgE which had already been subject to a log transformation). Missing genotypes were inferred using the -infer option available in Merlin. LD and haplotypes were assessed using the open source program Haploview (version 4.0) [16]. All markers were included in these analyses on a gene-by-gene basis, although only haplotypes present in $\geq 1 \%$ of the population were considered for associations to asthma. Empirical $\mathrm{p}$ values were determined by permutation $(\mathrm{n}=$ $1,000)$ and $p<0.05$ was regarded as statistically significant.

\section{Results}

\section{Characteristics of the Subjects}

In total, 696 unrelated subjects of Han ethnicity were included in this study (408 asthma cases and 288 controls). The incidence of asthma was higher in females than in males (58.2 vs. $41.8 \%$ ). The baseline $\mathrm{FEV}_{1}$ was significantly lower in asthmatics than normal controls (70.65 \pm 24.15 vs. $90.6 \pm 14.92 \%$ of predicted, $\mathrm{p}<$ $0.00001)$. One hundred and thirty-five (33\%) asthma subjects with baseline FEV1 $\geq 70 \%$ of predicted were examined using the airway challenge test; in all of these subjects, positive bronchial hyperresponsiveness was documented. The airway reversibility test was carried out in 
Table 1. Primers and PCR conditions for amplification of the PHF11 and DPP10 genes

\begin{tabular}{|c|c|c|c|c|c|}
\hline Markers & SNPs & Primers $\left(5^{\prime} \rightarrow 3^{\prime}\right)$ & $\begin{array}{l}\text { Restriction } \\
\text { enzymes }\end{array}$ & $\begin{array}{l}\mathrm{T} \\
{ }^{\circ} \mathrm{C}\end{array}$ & $\begin{array}{l}\mathrm{MgCl}_{2} \\
\mathrm{mM}\end{array}$ \\
\hline rs11619265 & $\mathrm{A} / \mathrm{G}$ & $\begin{array}{l}\text { F: AACATAGATGTTCTTACTTAG } \\
\text { R: ATCTCTAATAACTGAATGGTA }\end{array}$ & $R s a \mathrm{I}$ & 50 & 2 \\
\hline rs3765526 & $\mathrm{A} / \mathrm{G}$ & $\begin{array}{l}\text { F: GTTTTAAAGAAAGGTAAACAATT } \\
\text { R: CAAAGAGAATAGGTCTTGTTC }\end{array}$ & $\mathrm{NfeI}$ & 50 & 2 \\
\hline rs9526569 & $\mathrm{C} / \mathrm{T}$ & $\begin{array}{l}\text { F: CTAAGTTTCCACAATTAAAAG } \\
\text { R: GTCCCTTTGTATATCTTTGAG }\end{array}$ & HindIII & 50 & 2 \\
\hline rs1046295 & $\mathrm{G} / \mathrm{A}$ & $\begin{array}{l}\text { F: GCATCTCAACAAAGGTGGC } \\
\text { R: CATGACTCTTGGCTTAGGA }\end{array}$ & BsmAI & 55 & 2 \\
\hline rs16659 (15 bp) & $\mathrm{I} / \mathrm{D}$ & $\begin{array}{l}\text { F: GGAACACCATAATTTTGGTG } \\
\text { R: TCTTCAAGTCAACCCTCTTA }\end{array}$ & - & 50 & 2.5 \\
\hline rs953502 & $\mathrm{A} / \mathrm{G}$ & $\begin{array}{l}\text { F: TAACACGTTTCGAAACTGC } \\
\text { R: CTTCATTATAAGGTAAAGCTG }\end{array}$ & Fnu4HI & 50 & 2 \\
\hline rs7568000 & $\mathrm{C} / \mathrm{T}$ & $\begin{array}{l}\text { F: TAGGTCACCTTATTCTCAGT } \\
\text { R: CAGAATATCAGCATTGGGAA }\end{array}$ & AseI & 55 & 2 \\
\hline rs10208402 & $\mathrm{T} / \mathrm{C}$ & $\begin{array}{l}\text { F: GCCTCTAAAATGTGCAGATTT } \\
\text { R: CACTACATGGGAAGGGTAAAG }\end{array}$ & $M n l \mathrm{I}$ & 60 & 2 \\
\hline rs1430090 & $\mathrm{T} / \mathrm{G}$ & $\begin{array}{l}\text { F: CTAACTTCTGCCATGGTGAT } \\
\text { R: GACGAGACTTCTTTCTACCT }\end{array}$ & $B s r \mathrm{I}$ & 60 & 2 \\
\hline rs 17763180 & $\mathrm{~T} / \mathrm{C}$ & $\begin{array}{l}\text { F: GTTATAGAGTCCAAGTTCAG } \\
\text { R: TCCAAGTCTATCCTCCTTGA }\end{array}$ & $P v u \mathrm{II}$ & 50 & 2 \\
\hline rs12151526 & $\mathrm{A} / \mathrm{C}$ & $\begin{array}{l}\text { F: AGCACAAGATGCTTTTGCAA } \\
\text { R: TCTTGCTACCCTGTTTGAAT }\end{array}$ & $\operatorname{HinfI}$ & 50 & 2 \\
\hline
\end{tabular}

$\mathrm{T}=$ Annealing temperature $\mathrm{F}=$ forward $\mathrm{R}=$ reverse $\mathrm{I} / \mathrm{D}=$ insertion/deletion.

273 patients (67\%). The mean improvement in $\mathrm{FEV}_{1}$ was $26.36 \pm 14.27 \%$. The serum total IgE values in controls were within the normal range. Detailed characteristics of the individuals are listed in table 2.

\section{Association between Polymorphisms in PHF11 and}

DPP10 Genes and Asthma and Related Traits

We selected six polymorphisms in PHF11 and five polymorphisms in DPP10 for investigation. The markers in PHF11 covered $218 \mathrm{~kb}$. Three of these markers (rs3765526, rs9526569 and rs1046295) were either intronic to PHF11 or located in the 5 '-untranslated region (UTR). A proportion of these markers were extensively studied in the initial report on PHF11 associations [4]. Five markers in and around DPP10 were selected from $5^{\prime}$-upstream and the introns of splicing variants of exon Ia, IIs and Ic of the gene and covered $114 \mathrm{~kb}$. The marker information and allele genotype frequencies are listed in table 3. All SNPs met the criteria for the Hardy-Weinberg equilibrium in both case and control groups (data not shown).

Single marker analysis for associations showed that two markers in the PHF11 locus (rs1046295 and rs16659)
Table 2. Characteristics of the asthma patients $(n=408)$ and controls $(\mathrm{n}=288)$ included in this study

\begin{tabular}{lll}
\hline & Asthma & Controls \\
\hline $\begin{array}{l}\text { Mean age, years } \\
\quad \text { Range }\end{array}$ & $41.7 \pm 0.3$ & $45.1 \pm 0.7$ \\
Sex, n (\%) & $16-76$ & $22-72$ \\
$\quad$ Male & $170(41.8)$ & $158(55.0)$ \\
$\quad$ Female & $238(58.2)$ & $130(45.0)$ \\
$\log _{\text {IgE, U/l }}$ & $5.24 \pm 1.44$ & $3.64 \pm 1.10$ \\
Eosinophils, \% & $7.13 \pm 4.91$ & $2.19 \pm 0.93$ \\
Lung function & & \\
$\quad$ FEV $_{1}, \%$ & $70.65 \pm 24.15$ & $90.6 \pm 14.92$ \\
$\quad$ FEV $_{1} / \mathrm{FVC}, \%$ & $65.58 \pm 14.62$ & $81.53 \pm 9.52$ \\
\hline
\end{tabular}

were significantly associated with asthma (odds ratio, $\mathrm{OR}=1.32,95 \%$ confidence interval, $\mathrm{CI}=1.06-1.65, \mathrm{p}=$ 0.0096 , for rs 1046295 , and $\mathrm{OR}=1.41,95 \% \mathrm{CI}=1.12-1.75$, $\mathrm{p}=0.0026$, for rs 16659). Homozygote $\mathrm{G} / \mathrm{G}$ for rs 1046295 and homozygote $\mathrm{D} / \mathrm{D}$ for rs16659 insertion/deletion polymorphisms (IDPs) were significantly associated with the 
Table 3. Polymorphisms in the DPP10 and PHF11 genes genotyped in this study

\begin{tabular}{|c|c|c|c|c|c|c|}
\hline \multicolumn{2}{|l|}{ Markers } & \multirow[t]{2}{*}{ Location } & \multirow{2}{*}{$\begin{array}{l}\text { Gene } \\
\text { position }\end{array}$} & \multirow[t]{2}{*}{ Polymorphisms } & \multicolumn{2}{|l|}{ MAF } \\
\hline rs number & name & & & & asthma & controls \\
\hline \multicolumn{7}{|l|}{$D P P 10$} \\
\hline rs7568000 & $543 w t c 21 p$ & 191388 & & $\mathrm{C} / \mathrm{T}$ & $\mathrm{T}=0.33$ & $\mathrm{~T}=0.32$ \\
\hline rs10208402 & $543 w t c 91 p$ & 252279 & intron Ia & $\mathrm{T} / \mathrm{C}$ & $\mathrm{T}=0.35$ & $\mathrm{~T}=0.37$ \\
\hline rs1430090 & $543 w t c 122 p$ & 259007 & intron IIs & $\mathrm{A} / \mathrm{C}$ & $C=0.39$ & $C=0.35$ \\
\hline rs 17763180 & $543 w t c 124 p$ & 262881 & intron IIs & $\mathrm{T} / \mathrm{C}$ & $\mathrm{T}=0.12$ & $\mathrm{~T}=0.12$ \\
\hline rs12151526 & $16 w t c 104 p$ & 305609 & intron Ic & $\mathrm{G} / \mathrm{T}$ & $\mathrm{T}=0.34$ & $\mathrm{~T}=0.36$ \\
\hline \multicolumn{7}{|l|}{ PHF11 } \\
\hline rs11619265 & b1_1 & 141478 & & $\mathrm{~A} / \mathrm{G}$ & $\mathrm{A}=0.46$ & $\mathrm{~A}=0.50$ \\
\hline rs3765526 & b4_2 & 178972 & intron 5 & $\mathrm{~A} / \mathrm{G}$ & $\mathrm{A}=0.48$ & $\mathrm{G}=0.49$ \\
\hline rs9526569 & b5_2 & 186064 & intron 9 & $\mathrm{C} / \mathrm{T}$ & $C=0.20$ & $C=0.24$ \\
\hline rs1046295 & b5_3 & 187062 & $3^{\prime}$-UTR & $\mathrm{G} / \mathrm{A}$ & $\mathrm{A}=0.45$ & $\mathrm{G}=0.48$ \\
\hline rs16659 & 44593_15bp & 191057 & & $\mathrm{I} / \mathrm{D}$ & $\mathrm{I}=0.45$ & $\mathrm{D}=0.46$ \\
\hline rs953502 & b38_1 & 361086 & & $\mathrm{~A} / \mathrm{G}$ & $\mathrm{G}=0.10$ & $\mathrm{G}=0.09$ \\
\hline
\end{tabular}

Marker names, locations and positions of the gene were reported previously $[4,5]$. MAF $=$ Minor allele frequency. rs16659 is an insertion/deletion polymorphism marker.

Table 4. Association between asthma and polymorphisms of the genomic regions of the PHF11 and DPP10 genes

\begin{tabular}{|c|c|c|c|c|c|c|c|c|}
\hline \multirow[t]{2}{*}{ Markers } & \multirow{2}{*}{$\begin{array}{l}\text { Allele } 1 / \\
\text { allele } 2\end{array}$} & \multicolumn{2}{|c|}{ Allele 2 frequency } & \multicolumn{2}{|c|}{ Allele 2 vs. allele 1 analysis } & \multicolumn{3}{|c|}{ Genotype analysis } \\
\hline & & asthma & controls & $\mathrm{p}$ & OR (95\% CI) & asthma $^{a}$ & controls $^{\mathrm{a}}$ & $\mathrm{p}$ \\
\hline \multicolumn{9}{|l|}{ PHF11 } \\
\hline rs11619265 & $\mathrm{G} / \mathrm{A}$ & 0.46 & 0.50 & 0.25 & $0.86(0.66-1.11)$ & $110 / 149 / 85$ & $54 / 101 / 52$ & 0.29 \\
\hline rs3765526 & $\mathrm{A} / \mathrm{G}$ & 0.52 & 0.49 & 0.37 & $0.90(0.71-1.13)$ & $95 / 200 / 83$ & $63 / 140 / 69$ & 0.58 \\
\hline rs9526569 & $\mathrm{T} / \mathrm{C}$ & 0.20 & 0.24 & 0.18 & $0.83(0.63-1.09)$ & $258 / 116 / 23$ & $165 / 104 / 15$ & 0.13 \\
\hline rs1046295 & $\mathrm{A} / \mathrm{G}$ & 0.55 & 0.48 & 0.0096 & $1.32(1.06-1.65)$ & $123 / 200 / 83$ & $63 / 150 / 75$ & 0.03 \\
\hline rs16659 & $\mathrm{I} / \mathrm{D}$ & 0.55 & 0.46 & 0.0026 & $1.41(1.13-1.75)$ & $112 / 204 / 75$ & $56 / 143 / 77$ & 0.007 \\
\hline rs953502 & $\mathrm{A} / \mathrm{G}$ & 0.10 & 0.09 & 0.86 & $0.95(0.50-1.78)$ & $317 / 75 / 1$ & $182 / 35 / 3$ & 0.17 \\
\hline \multicolumn{9}{|l|}{$D P P 10$} \\
\hline rs7568000 & $\mathrm{C} / \mathrm{T}$ & 0.33 & 0.32 & 0.84 & $0.97(0.72-1.30)$ & $185 / 175 / 45$ & $132 / 122 / 30$ & 0.96 \\
\hline rs10208402 & $\mathrm{C} / \mathrm{T}$ & 0.35 & 0.37 & 0.54 & $0.93(0.73-1.18)$ & $174 / 176 / 53$ & $109 / 145 / 33$ & 0.21 \\
\hline rs1430090 & $\mathrm{A} / \mathrm{C}$ & 0.39 & 0.35 & 0.12 & $0.83(0.66-1.05)$ & $144 / 199 / 57$ & $113 / 149 / 26$ & 0.11 \\
\hline rs17763180 & $\mathrm{C} / \mathrm{T}$ & 0.12 & 0.12 & 0.81 & $1.06(0.67-1.66)$ & $311 / 79 / 9$ & $222 / 60 / 6$ & 0.47 \\
\hline rs12151526 & $\mathrm{G} / \mathrm{T}$ & 0.34 & 0.36 & 0.45 & $0.91(0.71-1.16)$ & $178 / 159 / 54$ & $113 / 136 / 35$ & 0.17 \\
\hline
\end{tabular}

Significant values are shown in bold. rs16659 is an insertion/deletion (I/D) polymorphism marker.

a The three values represent the number of major allele homozygote/heterozygote/minor allele homozygote carriers.

development of asthma ( $\mathrm{p}=0.03$ and 0.007 , respectively; table 4).

We further searched for associations between polymorphic markers in PHF11 and DPP10 and a number of quantitative asthma-related traits using Merlin. A single marker in DPP10, rs10208402, demonstrated highly significant associations with both $\log$-transformed $\operatorname{IgE}(\mathrm{p}=$
$0.00031)$ and the percentage of eosinophils $(\mathrm{p}=0.0049)$. A more moderate association was also observed between marker rs1430090 (also in DPP10) and $\mathrm{FEV}_{1}(\mathrm{p}=0.038)$. A single marker in PHF11 (rs11619265) was significantly associated with the percentage of eosinophils ( $\mathrm{p}=0.0078)$, and the same marker showed a trend towards significance for $\log$-transformed $\operatorname{IgE}(\mathrm{p}=0.083)$. 
Table 5. Haplotypes of PHF11, DPP10 and asthma

\begin{tabular}{|c|c|c|c|c|c|c|}
\hline \multirow[t]{2}{*}{ Haplotype } & & \multicolumn{3}{|c|}{ Frequencies } & \multirow{2}{*}{$\begin{array}{l}\chi^{2} \\
\text { test }\end{array}$} & \multirow{2}{*}{$\begin{array}{l}\mathrm{p} \\
\text { value }\end{array}$} \\
\hline & & total & asthma & controls & & \\
\hline \multicolumn{7}{|l|}{ PHF11 } \\
\hline H1 & GGTADA & 0.322 & 0.332 & 0.309 & 0.736 & 0.3909 \\
\hline $\mathrm{H} 2$ & AATGIA & 0.170 & 0.152 & 0.194 & 4.14 & 0.0419 \\
\hline H3 & AACGIA & 0.144 & 0.124 & 0.172 & 6.248 & 0.0124 \\
\hline $\mathrm{H} 4$ & AGTADA & 0.072 & 0.073 & 0.070 & 0.073 & 0.7865 \\
\hline H5 & GATGIA & 0.069 & 0.068 & 0.071 & 0.036 & 0.8504 \\
\hline H6 & CGTADG & 0.036 & 0.039 & 0.033 & 0.361 & 0.5478 \\
\hline $\mathrm{H} 7$ & GATADA & 0.024 & 0.030 & 0.016 & 2.925 & 0.0872 \\
\hline $\mathrm{H} 8$ & GGCGIA & 0.021 & 0.019 & 0.025 & 0.569 & 0.4508 \\
\hline H9 & AATGIG & 0.021 & 0.022 & 0.020 & 0.058 & 0.809 \\
\hline H10 & AACGIG & 0.019 & 0.016 & 0.023 & 0.763 & 0.3823 \\
\hline \multicolumn{7}{|l|}{ DPP10 } \\
\hline $\mathrm{H} 1$ & CCCCG & 0.132 & 0.138 & 0.123 & 0.604 & 0.437 \\
\hline $\mathrm{H} 2$ & TCCCC & 0.115 & 0.118 & 0.110 & 0.259 & 0.611 \\
\hline $\mathrm{H} 3$ & СТССС & 0.098 & 0.101 & 0.092 & 0.314 & 0.5753 \\
\hline $\mathrm{H} 4$ & TCACG & 0.096 & 0.095 & 0.097 & 0.0070 & 0.932 \\
\hline H5 & CCACT & 0.092 & 0.097 & 0.085 & 0.513 & 0.474 \\
\hline H6 & CCACG & 0.091 & 0.087 & 0.098 & 0.494 & 0.4824 \\
\hline H7 & CTACG & 0.090 & 0.084 & 0.097 & 0.697 & 0.4038 \\
\hline $\mathrm{H} 8$ & CTATG & 0.077 & 0.066 & 0.092 & 3.105 & 0.0781 \\
\hline H9 & TCACT & 0.045 & 0.042 & 0.049 & 0.325 & 0.5689 \\
\hline H10 & CTATT & 0.043 & 0.043 & 0.042 & 0.0060 & 0.94 \\
\hline H11 & CCATT & 0.041 & 0.045 & 0.035 & 0.82 & 0.3653 \\
\hline H12 & TCATT & 0.017 & 0.014 & 0.020 & 0.742 & 0.3889 \\
\hline H13 & TTCCG & 0.013 & 0.017 & 0.007 & 2.313 & 0.1283 \\
\hline H14 & TTATT & 0.011 & 0.012 & 0.010 & 0.037 & 0.8483 \\
\hline H15 & TTACG & 0.011 & 0.011 & 0.011 & 0.0070 & 0.9348 \\
\hline H16 & TTACT & 0.011 & 0.010 & 0.011 & 0.013 & 0.9101 \\
\hline
\end{tabular}

PHF11 marker order: rs1161926-rs3765526-rs9526569-rs1046295-rs16659-rs953502; rs16695 is an insertion/ deletion marker. DPP10 marker order: rs756800-rs10208402-rs1430090-rs17763810-rs12151526. Significant differences in haplotypes are shown in bold.

\section{Haplotype Analyses and LD Tests}

Haplotype analyses of all markers gene by gene (including haplotypes present in $\geq 1 \%$ of the population genotyped) revealed a moderate association between two PHF11 haplotypes and asthma (AATGIA, $\chi^{2}=4.14, \mathrm{p}=$ 0.0419 , and AACGIA, $\chi^{2}=6.248, p=0.0124$ ). Only one haplotype remained significant after 1,000 permutations (haplotype $=$ AACGIA, permutation $\mathrm{p}=0.0240$ ). This haplotype was significantly underrepresented in asthmatics compared with controls, with case and control frequencies of 0.124 and 0.172 , respectively. This haplotype therefore appears to confer protection against asthma. No haplotypes in DPP10 showed a consistent association with asthma (table 5).

Polymorphisms of DPP10 and PHF11 and Asthma

\section{Discussion}

We performed a case-control study to test the association between polymorphisms in PHF11 and DPP10 and asthma, as well as a number of quantitative intermediate traits in 408 patients and 288 controls in a Han Chinese population. Two markers in PHF11, rs1046295 and rs16659, were found to be significantly associated with asthma, and a third marker, rs11619265, with peripheral blood eosinophils. Markers in DPP10 were not significantly associated with asthma, however highly significant associations were observed with both log-transformed serum IgE (rs10208402) and the percentage of peripheral blood eosinophils (rs10208402). A more mod-

Respiration 2010;79:17-24 
erate association was also noted between DPP10 (rs1430090) and $\mathrm{FEV}_{1}$. One haplotype in PHF11 was shown to confer significant protection against the risk of asthma. Together, these results provide support for the hypothesis that polymorphisms in PHF11 and DPP10 affect the susceptibility to asthma and/or asthma-related traits.

PHF11, encoding a plant homeodomain finger protein, regulates transcriptional activity with multiple splice variants in T and B cells [4]. A recent study has shown that PHF11 regulates the expression of Th1-type cytokine genes, and reduced expression of PHF11 in atopic dermatitis (a disease that commonly presents concomitant with asthma) causes strong Th2 responses characterizing asthma and allergic diseases [9]. In PHF11, markers rs3765526 and rs1046295 have been associated with asthma in the general Australian population and are significantly linked to severe asthma in unrelated British individuals [4]. In an extensive study testing positionally cloned asthma genes, several SNPs in PHF11 were reported to be marginally associated with childhood asthma in European-American and Hispanic families [11].

The positive association between rs1046295 and asthma was confirmed by the initial positional cloning that first implicated PHF11 in the etiology of asthma. Marker rs1046295 is located in the 3'-UTR of PHF11 and has also been associated with childhood atopic dermatitis [17]. The $\mathrm{G}$ allele of rs 1046295 is preferentially transmitted to children with atopic dermatitis and has been associated with decreased PHF11 RNA in Th1 cells [9]. Marker rs16659 is $4 \mathrm{~kb}$ away from rs1046295, positioned within the $5^{\prime}$-UTR of RCBTB1, and shows strong LD with rs1046295 $\left(\mathrm{r}^{2}=0.9\right.$, data not shown). SETDB2 and RCBTB1 colocalize with PHF11 within the same LD blocks. They may also be important to the disease, particularly SETDB2, which has an expression profile similar to PHF11 in immune-related cells [4]. In the present study, genetic markers in PHF11 were closely associated with overall asthma susceptibility but not linked to asthma-related phenotypes, e.g. serum total IgE. This can be due to the fact that for the overall disease risk, phenotypes are influenced by numerous biological pathways that interact with environmental factors [18, 19].

DPP10 encodes a dipeptidyl peptidase, which can cut two peptides from $\mathrm{N}$-termini of certain proinflammatory chemokines, but it is still unknown whether the removal of two peptides activates or deactivates them. DPP10 is prominently expressed in the brain as well as adrenal glands and trachea. In situ hybridization showed that DPP10 is expressed in neuronal populations also known to express Kv4 products, and DPP10 protein was found to coprecipitate with $\mathrm{Kv} 4.2$ channel complexes from brain membranes [20].

In the initial positional cloning study of DPP10, marker rs1430090 was strongly associated with asthma. In particular, haplotype rs1430090-D2S308 was positively associated with severe asthma in German children. The marker rs1430090 was also suggested to affect DPP10 expression by altering the sequence of the known promoter element $(\mathrm{CdxA})$ adjacent to one of the alternative exons [5]. The associations between polymorphisms in DPP10 and asthma or asthma-related traits were not found in two family-based samples [11]. In our study, marker rs10208402 in DPP10 was strongly associated with peripheral blood eosinophil (\%) and serum total IgE in patients with asthma. The same marker correlated strongly with IgE in Australian and British families [5]. Marker rs1430090 was also associated with $\mathrm{FEV}_{1}$ in asthma patients.

The discrepancies observed between studies could reflect true differences in the genetic effects of DPP10 variants or in the patterns of LD between typed and true causative variants $[5,21]$. Also, the extent and nature of gene-gene and gene-environment interactions may vary between populations [22]. Environmental exposure, which is crucial for the expression of asthma, may well vary between populations [23]. In addition, differences in the study design may also influence the type of effect observed. In previous studies, the subjects have been children, whereas our study includes only adults. Age is known to have important effects on the expression of asthma. Longitudinal studies have indicated that about $50 \%$ of children with asthma will outgrow the symptoms after a numbers of years [24].

A higher serum total IgE is a robust risk factor for asthma regardless of the specific IgE to allergen [25]. Our study clearly demonstrates that markers within DPP10 associate with several asthma-related traits. This may be a consequence of allelic heterogeneity whereby distinct alleles yield distinct phenotypic consequences, or an effect of pleiotropy whereby a single allele yields a variety of pathogenic effects. Different asthma-related phenotypes are certainly known to map to different locations within this broad linkage region $[8,26,27]$.

The case-control study design adopted in this study is a common strategy in genetic studies of complex diseases such as asthma [18, 28]. The advantage of association studies is that this approach will detect the genes with smaller effects in sample sizes comparable to those used in linkage analyses. Statistically, there is increased power 
in studying the equivalent number of individuals in casecontrol association studies than in family-based studies [18]. However, small population sizes, population stratification, phenotype heterogeneity and varied environmental exposure are often blamed for negative replication of initially positive associations $[10,29]$. The current study has some advantages. It was based on a relatively large study cohort including nearly 700 unrelated individuals (408 patients and 288 controls) with Han Chinese ethnicity recruited from the Northern region of China, representing a relatively homogeneous group. The diagnosis of asthma was defined by the present asthmatic symptoms plus an explicit diagnostic test such as bronchial hyperresponsiveness or positive airway reversibility [30]; this study includes adults only, thus, to a greater extent, avoiding the possibility of phenotypic heterogeneity which may cause spurious associations, as evidence shows that childhood and adult asthma differ in several aspects $[31,32]$.

In conclusion, our findings that genetic variants in PHF11 and DPP10 genes partially contribute to asthma susceptibility and asthma-related phenotypes are consis- tent with the known genetic biology of asthma that several genes at distinct chromosomal regions confer the risk of asthma, having a larger or smaller effect according to environmental risk exposure [27, 33, 34]. However, it should be pointed out that the functional variants in the two loci and the mechanisms by which they mediate the phenotype have yet to be elucidated. Large-scale studies of these genes in other populations, particularly in combination with the underlying disease-causing mechanism(s), are required in order to accurately predict the disease risk conferred by these loci.

\section{Acknowledgment}

This work was funded by the New Century Excellent Talents Program from the Chinese Ministry of Education (NCET-060156) and a grant from the National Natural Sciences Foundation of China (No. 30470767). We thank Jun Gao and Yang Zhao for their help in collecting the blood samples. We are also indebted to Haijuan He and Ruiqi Wang for their help in serum total $\operatorname{IgE}$ measurements.

\section{References}

1 Cookson W, Moffatt M: Making sense of asthma genes. N Engl J Med 2004;351:17941796.

2 Daniels SE, Bhattacharrya S, James A, Leaves NI, Young A, Hill MR, Faux JA, Ryan GF, le Souef PN, Lathrop GM, Musk AW, Cookson WO: A genome-wide search for quantitative trait loci underlying asthma. Nature 1996; 383:247-250.

-3 Van Eerdewegh P, Little RD, Dupuis J, Del Mastro RG, Falls K, Simon J, Torrey D, Pandit S, McKenny J, Braunschweiger K, Walsh A, Liu Z, Hayward B, Folz C, Manning SP, Bawa A, Saracino L, Thackston M, Benchekroun Y, Capparell N, Wang M, Adair R, Feng Y, Dubois J, FitzGerald MG, Huang H, Gibson R, Allen KM, Pedan A, Danzig MR, Umland SP, Egan RW, Cuss FM, Rorke S, Clough JB, Holloway JW, Holgate ST, Keith TP: Association of the ADAM33 gene with asthma and bronchial hyperresponsiveness. Nature 2002;418:426-430.

4 Zhang Y, Leaves NI, Anderson GG, Ponting $\mathrm{CP}$, Broxholme J, Holt R, Edser P, Bhattacharyya S, Dunham A, Adcock IM, Pulleyn L, Barnes PJ, Harper JI, Abecasis G, Cardon L, White M, Burton J, Matthews L, Mott R, Ross M, Cox R, Moffatt MF, Cookson WO: Positional cloning of a quantitative trait locus on chromosome 13q14 that influences immunoglobulin E levels and asthma. Nat Genet 2003;34:181-186.
5 Allen M, Heinzmann A, Noguchi E, Abecasis G, Broxholme J, Ponting CP, Bhattacharyya S, Tinsley J, Zhang Y, Holt R, Jones EY, Lench N, Carey A, Jones H, Dickens NJ, Dimon C, Nicholls R, Baker C, Xue L, Townsend E, Kabesch M, Weiland SK, Carr D, von Mutius E, Adcock IM, Barnes PJ, Lathrop GM, Edwards M, Moffatt MF, Cookson WO: Positional cloning of a novel gene influencing asthma from chromosome 2q14. Nat Genet 2003;35:258-263.

6 Laitinen T, Polvi A, Rydman P, Vendelin J, Pulkkinen V, Salmikangas P, Makela S, Rehn M, Pirskanen A, Rautanen A, Zucchelli M, Gullsten H, Leino M, Alenius H, Petays T, Haahtela T, Laitinen A, Laprise C, Hudson TJ, Laitinen LA, Kere J: Characterization of a common susceptibility locus for asthmarelated traits. Science 2004;304:300-304.

7 Moffatt MF, Kabesch M, Liang L, Dixon AL, Strachan D, Heath S, Depner M, von Berg A, Bufe A, Rietschel E, Heinzmann A, Simma B, Frischer T, Willis-Owen SA, Wong KC, Illig T, Vogelberg C, Weiland SK, von Mutius E, Abecasis GR, Farrall M, Gut IG, Lathrop GM, Cookson WO: Genetic variants regulating ORMDL3 expression contribute to the risk of childhood asthma. Nature 2007;448: 470-473.
-8 Nicolae D, Cox NJ, Lester LA, Schneider D, Tan Z, Billstrand C, Kuldanek S, Donfack J, Kogut P, Patel NM, Goodenbour J, Howard T, Wolf R, Koppelman GH, White SR, Parry R, Postma DS, Meyers D, Bleecker ER, Hunt JS, Solway J, Ober C: Fine mapping and positional candidate studies identify HLA-G as an asthma susceptibility gene on chromosome 6p21. Am J Hum Genet 2005;76:349357.

9 Clarke E, Rahman N, Page N, Rolph MS, Stewart GJ, Jones GJ: Functional characterization of the atopy-associated gene PHF11. J Allergy Clin Immunol 2008; $121: 1148-$ 1154.e3.

10 Gao J, Shan G, Sun B, Thompson PJ, Gao X: Association between polymorphism of tumour necrosis factor alpha-308 gene promoter and asthma: a meta-analysis. Thorax 2006;61:466-471.

11 Hersh CP, Raby BA, Soto-Quiros ME, Murphy AJ, Avila L, Lasky-Su J, Sylvia JS, Klanderman BJ, Lange C, Weiss ST, Celedon JC: Comprehensive testing of positionally cloned asthma genes in two populations. Am J Respir Crit Care Med 2007;176:849-857.

12 Sohn MH, Lee JH, Kim KW, Kim SW, Lee SH, Kim KE, Kim KH, Lee CG, Elias JA, Lee MG: Genetic variation in the promoter region of chitinase 3-like 1 is associated with atopy. Am J Respir Crit Care Med 2009;179: 449-456. 
13 Standards for the diagnosis and care of patients with chronic obstructive pulmonary disease (COPD) and asthma. This official statement of the American Thoracic Society was adopted by the ATS Board of Directors, November 1986. Am Rev Respir Dis 1987; 136:225-244.

14 Lathrop GM: Estimating genotype relative risks. Tissue Antigens 1983;22:160-166.

- 15 Abecasis GR, Cherny SS, Cookson WO, Cardon LR: Merlin - rapid analysis of dense genetic maps using sparse gene flow trees. Nat Genet 2002;30:97-101.

16 Barrett JC, Fry B, Maller J, Daly MJ: Haploview: analysis and visualization of $\mathrm{LD}$ and haplotype maps. Bioinformatics 2005;21: 263-265.

17 Jang N, Stewart G, Jones G: Polymorphisms within the PHF11 gene at chromosome 13q14 are associated with childhood atopic dermatitis. Genes Immun 2005;6:262-264.

18 Ober C, Hoffjan S: Asthma genetics 2006: the long and winding road to gene discovery. Genes Immun 2006;7:95-100.

19 Raby BA, Klanderman B, Murphy A, Mazza S, Camargo CA Jr, Silverman EK, Weiss ST: A common mitochondrial haplogroup is associated with elevated total serum IgE levels. J Allergy Clin Immunol 2007;120:351-358.

20 Zagha E, Ozaita A, Chang SY, Nadal MS, Lin U, Saganich MJ, McCormack T, Akinsanya KO, Qi SY, Rudy B: DPP10 modulates Kv4mediated A-type potassium channels. J Biol Chem 2005;280:18853-18861.
21 Gabriel SB, Schaffner SF, Nguyen H, Moore JM, Roy J, Blumenstiel B, Higgins J, DeFelice M, Lochner A, Faggart M, Liu-Cordero SN, Rotimi C, Adeyemo A, Cooper R, Ward R, Lander ES, Daly MJ, Altshuler D: The structure of haplotype blocks in the human genome. Science 2002;296:2225-2229.

22 Orsmark-Pietras C, Melen E, Vendelin J, Bruce S, Laitinen A, Laitinen LA, Lauener R, Riedler J, von Mutius E, Doekes G, Wickman M, van Hage M, Pershagen G, Scheynius A, Nyberg F, Kere J: Biological and genetic interaction between tenascin $\mathrm{C}$ and neuropeptide $S$ receptor 1 in allergic diseases. Hum Mol Genet 2008;17:1673-1682.

23 Ferreira MA, O’Gorman L, Le Souef P, Burton PR, Toelle BG, Robertson CF, Visscher PM, Martin NG, Duffy DL: Robust estimation of experimentwise $\mathrm{p}$ values applied to a genome scan of multiple asthma traits identifies a new region of significant linkage on chromosome 20q13. Am J Hum Genet 2005; 77:1075-1085.

24 Barbee RA, Murphy S: The natural history of asthma. J Allergy Clin Immunol 1998;102: S65-S72.

25 Sherrill DL, Lebowitz MD, Halonen M, Barbee RA, Burrows B: Longitudinal evaluation of the association between pulmonary function and total serum IgE. Am J Respir Crit Care Med 1995;152:98-102.

26 Ober C, Pan L, Phillips N, Parry R, Kurina LM: Sex-specific genetic architecture of asthma-associated quantitative trait loci in a founder population. Curr Allergy Asthma Rep 2006;6:241-246.

-27 Blumenthal MN, Ober C, Beaty TH, Bleecker ER, Langefeld CD, King RA, Lester L, Cox N, Barnes K, Togias A, Mathias R, Meyers DA, Oetting W, Rich SS: Genome scan for loci linked to mite sensitivity: the collaborative study on the genetics of asthma (CSGA). Genes Immun 2004;5:226-231.
28 Pearson TA, Manolio TA: How to interpret a genome-wide association study. JAMA 2008; 299:1335-1344

29 Ioannidis JP, Ntzani EE, Trikalinos TA, Contopoulos-Ioannidis DG: Replication validity of genetic association studies. Nat Genet 2001;29:306-309.

30 Lemanske RF Jr, Busse WW: Asthma. JAMA 1997;278:1855-1873.

-31 Jenkins HA, Cherniack R, Szefler SJ, Covar R, Gelfand EW, Spahn JD: A comparison of the clinical characteristics of children and adults with severe asthma. Chest 2003;124: 1318-1324

>32 Kjellman B, Gustafsson PM: Asthma from childhood to adulthood: asthma severity, allergies, sensitization, living conditions, gender influence and social consequences. Respir Med 2000;94:454-465.

-33 Hoffjan S, Nicolae D, Ostrovnaya I, Roberg K, Evans M, Mirel DB, Steiner L, Walker K, Shult P, Gangnon RE, Gern JE, Martinez FD, Lemanske RF, Ober C: Gene-environment interaction effects on the development of immune responses in the 1st year of life. Am J Hum Genet 2005;76:696-704.

34 Weiss LA, Lester LA, Gern JE, Wolf RL, Parry R, Lemanske RF, Solway J, Ober C: Variation in ITGB3 is associated with asthma and sensitization to mold allergen in four populations. Am J Respir Crit Care Med 2005; 172: 67-73. 